\title{
Family Environment and Social Sciences Learning Outcomes during the Covid-19 Pandemic
}

\section{Ni Luh Putu Sintya Pramitha Dewi ${ }^{1 *}$, Ni Nyoman Ganing ${ }^{2}$}

1,2 Universitas Pendidikan Ganesha, Bali, Indonesia

\author{
A R T I C LE I N F O \\ Article history: \\ 25 December 2020 \\ Received in revised form \\ 11 January 2021 \\ Accepted 25 January \\ 2021 \\ Available online 25 \\ February 2021

\section{Kata Kunci: \\ Lingkungan Keluarga,} \\ Hasil Belajar. \\ Keywords: \\ Family Environment, \\ Learning Outcomes
}

\begin{abstract}
A B S T R A K
Penelitian ini dilakukan atas dasar banyaknya faktor yang dapat mempengaruhi keberhasilan belajar dan berdampak pada hasil belajar siswa. Penelitian ini bertujuan untuk mengetahui hubungan yang signifikan lingkungan keluarga dengan hasil belajar IPS selama masa pandemi COVID-19. Jenis penelitian ini adalah penelitian expost facto. Jumlah populasi dalam penelitian ini yaitu 57 orang siswa dan jumlah sampel penelitian sama dengan jumlah populasi yaitu sebanyak 57 orang siswa. Metode pengumpulan data pada penelitian ini menggunakan metode non tes yaitu kuesioner untuk variabel bebas lingkungan keluarga dan pencatatan dokumen untuk variabel terikat hasil belajar IPS, data dianalisis menggunakan uji analisis regresi sederhana. Berdasarkan hasil analisis dengan taraf signifikansi 5\% diperoleh bahwa terdapat hubungan yang signifikan lingkungan keluarga dengan hasil belajar IPS selama masa pandemi COVID-19 dengan $r_{x y}=0,398$ dan besar kontribusi 15,8\%. Berdasarkan hasil tersebut dapat disimpulkan bahwa lingkungan keluarga dapat mempengaruhi hasil belajar siswa khususnya pada mata pelajaran IPS.
\end{abstract}

\begin{abstract}
A B S T R A C T
This research was conducted basis on many factors that can affect learning success and have an impact on student learning outcomes. This research aims to determine the significant correlation between family environment with social sciences learning outcomes during the COVID-19 pandemic. The research design of this study is ex-post facto research. The population in this study was 57 students and the number of samples was the same as the population, 57 students. Data collection methods in this study used non-test methods, that are questionnaire for the independent variable of the family environment and document recording for the dependent variable social sciences learning outcomes, the data were analysed using simple regression analysis. Based on the results of the analysis with a significance level of 5\%, it was found that there was a significant correlation between the family environment and social sciences learning outcomes during the COVID-19 pandemic with rxy =0,398 and a large contribution of 15,8\%. Based on these results it can be concluded that the family environment can affect student learning outcomes especially social sciences subjects.
\end{abstract}

\section{Introduction}

Covid-19 (Corona Virus Disease 2019) pandemic first reported in Wuhan, China at the end of 2019 and transmitted to Indonesia at the begining of 2020 (Cho \& Hong, 2021; Crawford et al., 2020). Almost all countries have experienced the impacts of this pandemic, even many countries level up their security by setting lockdown status and taking other anticipatory in other to stop the spread of COVID-19 virus. The effects of this pandemic were many sectors that experience the direct impact, and one of it is the education sector (Wargadinata et al., 2020). The COVID-19 pandemic causes schools have to close to prevent the spread of COVID-19. Even though the schools were close, the teaching and learning activity was consistently continued. However, the learning system was change into online learning from home. This online learning is a learning activity that is done via internet media and supported by cell phones and computers (Satrianingrum \& Prasetyo, 2020).

The online learning was greatly different with previous learning activities (Dwivedi et al., 2020). Online learning is more emphasis on students related to their accuracy and foresight in receiving, understanding, and processing information that presented online by the teacher (Handayani et al., 2020). There were many problems that occurred in the online learning process, this online learning is extremely difficult to focus on learning activity due to the inconvenient home atmosphere, the limited internet quota which is link during online learning as well as some other problems that occurred during online learning. 
Moreover, online learning cause a lack of interaction between teacher and students, and vice versa. The lack of interaction can slow down the formation of value in online teaching and learning process. The online learning that currently being carried out is something new to teachers and students (Ding et al., 2020; Sadikin \& Hamidah, 2020).

Based on the results of the interview and observation that conducted in the fourth-grade students of SD Gugus I in Tabanan district, there were several problems that have occurred during the online learning process. First, during COVID-19 pandemic the teaching-learning process was carried out online from each students' home. Thus, the teachers were very difficult in providing guidance and delivering the subjects matter. Furthermore, during the online teaching and learning process, there were also obstacles which the supporting tools in the form of cell phones were limited. Most of the students did not have cell phone, so they have to used their parents' cell phones. It caused the teachers were difficult to communicate directly to the students. Second, teachers have lack of knowledge in using the supporting tools as computer in the online learning activities and have limited skill in operating supporting media such as zoom, google meet, and many others. So that, the teachers also rely on WhatsApp Group in delivering subject materials. Third, when the teachers provided a material that contains daily life's problem, the students often could not find the solution to solve the problems. It happened because of the lack of enthusiasm for student learning. Forth, social sciences subjects that are integrated with other subjects in the 2013 curriculum that make it more difficult for the students to understand the material. Its reason was the material in students' books were very minimal, while the material that must be conveyed to students was very dense. These problems caused the students learning outcomes could not be optimal especially in social sciences subjects.

The social sciences subjects (IPS) is one of subjects that must be taught at all levels of education in Indonesia, one of which is the elementary school level. In the curriculum of elementary school, social science subjects (IPS) studies about human interaction, social relations and social life (Putria et al., 2020; T. Rahayu \& Thomas, 2017). Furthermore, the scope of material in social sciences subjects' contents consists of human, place, environment, time, sustainability, change, social system, culture, economic behavior and well-being (Fanny \& Suardiman, 2013; Lenmita, 2020). IPS is a development of a thought's concept based on the reality of social condition in the surrounding environment (Barsihanor, 2016; Christina \& Kristin, 2016). It is means that the material of social sciences subjects (IPS) practically has the aim of developing the potency of the students to be heedful to social problems that occurred around, have a positive mental attitude, and have skill in dealing with every problem that occurred either in society or happen to themselves.

Educational activities always take place in an environment, one of it is family environment. The family environment is the first environment that children know than school environment and community. Family environment is the child's first educational environment that provides biological needs and provides an education so that it will produce individuals who can live in society (Purandina \& Winaya, 2020; Sri Rahayu, 2016). In the family environment, the children get the basic education first such as religious education, politeness, affection, and good habits. It shows that the children get more education. Family environment can affect students' learning success. Furthermore, the learning outcomes that have been obtained by the students are high and some are low. It happens because of the influence of the family environment situation and condition (H. Jamil, 2014; Lenmita, 2020; Rachmah, 2019). Factors that can give an impact to the students' learning outcomes such as the way parents educate the children, the relationship between family members, home atmosphere, family economic condition, parents' attention, and cultural background. All of these factors can affect the students' learning outcomes. If the students get a good situation and condition in their family environment, it will make the students success and get the optimal learning outcomes.

The importance of this research is to know whether family environment during the COVID-19 pandemic have an impact on students' learning outcomes, especially in social sciences subjects and the result of this research are used as guidance or success indicator in students' learning activities. Theoretically, family environment has a positive and significant correlation and learning outcomes, it is strengthened by several relevant research results including research which showed that there was a significant correlation between family environment and students' learning style and social sciences subject learning outcomes (Krisna, 2020). This study and this present study that is designed have a similarity. Research showed there was a direct impact of the family environment and learning facilities on students' social sciences achievement in terms of learning motivation (Rachmah, 2019). The difference between this study with this present study designed is the review of the dependent variable studied. Research showed that there was a significant and positive correlation between motivation, type of learning, family environment, and school environment on students' learning outcomes (Sulistiari, 2018). Research that conducted by Rahayu showed that there was a significant correlation between family 
environment and students' sociology learning outcomes (S. Rahayu, 2016). While the differences between this study with this present study designed are in the subjects and the object under study. This study researched about sociology subjects at the high school level, while this present study researched social sciences subjects at the fourth grade of elementary school level. Furthermore, the research conducted by Jamil shows that there was a positive and significant correlation on students; accounting learning outcomes, while the differences between this study and this present study designed are in the subjects and the object under study (H. Jamil, 2014). Moreover, the research that conducted by Monika showed that family environment had a positive effect on Indonesian learning outcomes (Monika, 2018). The differences between this study and this present study designed are in the subjects and the objects studied.

Based on all of the descriptions described above and previous research, a question raised about the significant correlation between the family environment and social science learning outcomes during the COVID-19 pandemic, and the research was designed at SD Gugus I Tabanan District especially in grade IV students who had been the novelty and uniqueness of this present study designed. Then, the objective of this study was to know the significant correlation between family environment and parents' attention and social sciences learning outcomes during the COVID-19 pandemic of the fourth-grade students of SD Gugus I, Tabanan District.

\section{Method}

The objective of this study was to know the significant correlation between family environment and social sciences learning outcomes during the COVID-19 pandemic. This study is categorized into expost facto research. In this present study, there are two variables which family environment $(\mathrm{X})$ as the independent variable and social sciences learning outcomes $(\mathrm{Y})$ as the dependent variable. The research design is presented as Figure 1.

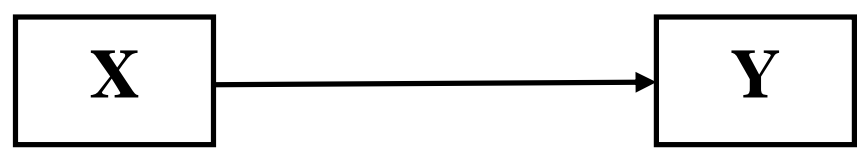

Figure 1. Research Design

The population of this study was all of the fourth-grade students of SD Gugus I, Tabanan District in the academic year 2020/2021 which consisted of 5 schools. The elementary schools of Gugus I Tabanan District are SD Negeri 1 Wanasari, SD Negeri 1 Sasandan, SD Negeri 1 Subamia, SD Negeri 2 Subamia, and SD Negeri 3 Denbantas with the total population was 57 students. The technique sampling that used in this present study was total sampling which the number of samples was equal to the population. If the total population is less than 100 people, the entire population is used as the research sample (Sugiyono, 2017). Thus, the sample in this present study was 57 students. The list of the research population and sample can be seen in table 1 .

Table 1. The List of The Research Population and Sample

\begin{tabular}{cccc}
\hline No & School & Population & Sample \\
\hline 1 & SD Negeri 1 Wanasari & 17 & 17 \\
2 & SD Negeri 1 Sesandan & 22 & 22 \\
3 & SD Negeri 1 Subamia & 10 & 10 \\
4 & SD Negeri 2 Subamia & 8 & 8 \\
5 & SD Negeri 3 Denbantas & 0 & 0 \\
\hline \multicolumn{2}{c}{ Total } & $\mathbf{5 7}$ & $\mathbf{5 7}$ \\
\hline
\end{tabular}

The data collection in this present study used non-test method with two techniques, questionnaire and document recording. The questionnaire was used to obtain the family environment data as independent variable data. There were 55 statements in the questionnaire and the respondents were the students' parents. Meanwhile, the document recording was used to obtain the social sciences learning outcomes data as the dependent variable data by recording the result of the social sciences subjects' final examination (UAS) of fourth grade in the odd semester of the academic year 2020/2021. The questionnaire of this present study was used four alternative answers in a modified Likert scale. Before distributing the questionnaire to the respondents, there were judges test and used test, then validity and reliability test are tested. These instrument tests were done to get an empirical description 
whether the questionnaire was valid and receivable or not. Based on the validity test of the questionnaire, there were 3 invalid statements and 52 valid statements. Furthermore, based the reliability test of the questionnaire, the reliability value was 0.931 which was in the very high category. The blueprint of the family environment questionnaire which is presented in table 2.

Table 2. The Blueprint of The Family Environment Questionnaire

\begin{tabular}{|c|c|c|c|}
\hline \multirow{2}{*}{ Indicator } & \multicolumn{2}{|l|}{ Number Item } & \multirow{2}{*}{ Total } \\
\hline & Positive (+) & Negative (-) & \\
\hline The way parents educate & $1,2,5,6,7,8,9,10$ & $3,4,11$ & 11 \\
\hline $\begin{array}{l}\text { The relationship between } \\
\text { family members }\end{array}$ & $12,14,15,16,17$ & 13 & 6 \\
\hline Home atmosphere & $18,19,20,21,22$ & - & 5 \\
\hline Family economic condition & $23,24,25,26,28,29$ & 27 & 7 \\
\hline Parents' attention & $\begin{array}{c}31,32,34,35,36,37,38,39,40,41,42 \\
43,44,45,46,47,48,50\end{array}$ & $30,33,49$ & 21 \\
\hline Cultural background & $51,52,53,55$ & 54 & 5 \\
\hline & Total & & 55 \\
\hline
\end{tabular}

The data obtained after distributing the questionnaire to the respondents, it continued to hypothesis test. Hypothesis test uses a simple regression test. However, before hypothesis test was carried out, the prerequisite test for data analysis was carried out in form of normality test and linearity test. Prerequisite test and hypothesis test were done by using SPSS 16.0 for windows.

\section{Result and Discussion}

\section{Finding}

The description family environment variable data were obtained that the mean was 168,32 , the median was 167,62 , the mode was 159,07 , the standard deviation was 13,37 , and the variance was 178,720 . The description of social sciences learning outcomes data were obtained that the mean was 79,88 , the median was 80,14 , the mode was 78,7 , the standard deviation was 5,30 , and the variance was 28,09. To know the correlation between these research variables, the hypothesis test was carried out. However, before hypothesis test was carried out, the prerequisite test for data analysis was carried out in form of normality test and linearity test. Prerequisite test and hypothesis test were carried out by using SPSS 16.0 for windows. The data distribution of normality test's result using the Kolmogorov-Smirnov test is presented in table 3 .

Table 3. The Data Distribution of Normality Test

\begin{tabular}{lcc}
\hline \multirow{2}{*}{ Analysis Unit } & \multicolumn{3}{c}{ Kolmogorov-Smirnov } \\
\cline { 2 - 3 } & $\mathbf{N}$ & Sig. \\
\hline Family Environment & 57 & 0.163 \\
Learning Outcomes & 57 & 0.739 \\
\hline
\end{tabular}

Based on the table 3 above, the result of the data distribution normality test using KolmogorovSmirnov can be seen that the sig. $>0,05$ which means the data distribution of family environment variable and the learning outcomes variables are normal. The linearity test was carried out by using the test on Deviation from Linearity in SPSS 16.0 for windows with significant level is $5 \%(0,05)$. This test was carried out to know the correlation between the independent variable and dependent variable. The result of the linearity test is shown in table 4.

Table 4. The Result of Linearity Test

\begin{tabular}{ccccccc}
\hline Analysis Unit & $\begin{array}{c}\text { Sum of } \\
\text { Squares }\end{array}$ & df & Mean Square & F & Sig. \\
\hline Family Environment*Learning Outcomes & 668.689 & 31 & 21.571 & 0.788 & 0.736 \\
\hline
\end{tabular}

Based on table 4 above, it shows the Sig. Deviation from Linearity of family environment*learning outcomes is 0.736 , which is higher than the $5 \%(0,05)$ significant level. It means that there is a linear 
correlation between the family environment and social sciences learning outcomes. After the prerequisite test was carried out, it continued to hypothesis test. Hypothesis test in this present study was assisted by SPSS 16.0 for windows. The hypothesis was carried out with a simple regression test. The hypothesis of this present study was there are a significant correlation between family environment and social sciences learning outcomes during the COVID-19 pandemic of the fourth-grade students of SD Gugus I Tabanan District. The results of the hypothesis testing can be seen in table 5, 6 and 7 .

Table 5. The Result of the $X^{*} Y$ Simple Regression Analysis

\begin{tabular}{lllllrc}
\hline & Model & Sum of Squares & df & Mean Square & F & Sig. \\
\hline 1 & Regression & 248.868 & 1 & 248.868 & 10.328 & .002 \\
& Residual & 1325.272 & 55 & 24.096 & & \\
& Total & 1574.140 & 56 & & & \\
\hline
\end{tabular}

Based on table 5 above, it shows that $\mathrm{F}_{\text {counted }}=10,328>\mathrm{F}_{\text {table }}=4,013$ which means the regression line is significant.

Table 6. The Result of the $\mathrm{X}^{*} \mathrm{Y}$ Correlation Coefficient Analysis

\begin{tabular}{ccccc}
\hline Model & R & R Square & Adjusted R Square & Std. Error of the Estimate \\
\hline 1 & .398 & .158 & .143 & 4.90875 \\
\hline
\end{tabular}

Based on the SPP calculation result in table 6 above, the contribution of family environment to the social sciences learning outcomes during the COVID-19 pandemic of the fourth-grade students of SD Gugus I, Tabanan District was found that the $r_{\text {counted }}=0,398>r_{\text {table }}=0,2609$ at the $5 \%$ significance level. From these results it is stated that the hypothesis is accepted, and it can be concluded that there is a significant correlation between family environment and social sciences learning outcomes during the COVID-19 pandemic of the fourth-grade students of SD Gugus I, Tabanan District with a large correlation of $39,8 \%$. Whereas, the coefficient of determination is $15,8 \%$.

Table 7. The Result of the $\mathrm{X}^{*} \mathrm{Y}$ Regression Equation

\begin{tabular}{|c|c|c|c|c|c|}
\hline \multirow[t]{2}{*}{ Model } & \multicolumn{2}{|c|}{$\begin{array}{c}\text { Unstandardized } \\
\text { Coefficients }\end{array}$} & \multirow{2}{*}{$\begin{array}{c}\text { Standardized Coefficients } \\
\text { Beta }\end{array}$} & \multirow[t]{2}{*}{$\mathbf{t}$} & \multirow[t]{2}{*}{ Sig. } \\
\hline & B & Std. Error & & & \\
\hline $\begin{array}{ll}1 & \text { (Constant) } \\
& \text { Family Environment }\end{array}$ & $\begin{array}{l}53.335 \\
.158\end{array}$ & $\begin{array}{l}8.284 \\
.049\end{array}$ & .398 & $\begin{array}{l}6.438 \\
3.214\end{array}$ & $\begin{array}{l}.000 \\
.002\end{array}$ \\
\hline
\end{tabular}

The analysis result in table 7 shows that the regression equation of the correlation between family environment and social sciences learning outcomes during the COVID-19 pandemic of the fourthgrade students of SD Gugus I, Tabanan District is as follows.

$$
\mathrm{Y}=53,335+0,158 \mathrm{X}
$$

The equation above shows that the value of family environment coefficient $(X)=0,158$ which means there is a positive correlation between $\mathrm{X}$ variable and $\mathrm{Y}$ variable. Every improvement in the family environment, there will be an improvement in social sciences learning outcomes of 0,158 at a constant of 53.335 .

\section{Discussion}

The success of students' social sciences learning outcomes highly depends on factors that involve it. The students' learning outcomes are influenced by internal and external factors. The internal factors are the factors that affect the students' learning outcomes that come from their own self (Dahlstrom-Hakki et al., 2020). Whereas, external factors are factors that affect the students' learning outcomes that come from the outside of the students (Brooman \& Darwent, 2014). Thus, family environment is one of the external factors that affects the students' social sciences learning outcomes. Learning outcomes are the abilities that achieved by the students after following the learning process. The learning process always take place in an environment, one of it is family environment. As it is known that the family environment is very crucial for the students' education success. Family environment is the first educational environment that the students know before school environment and other environments (Agot et al., 2019). The level of students' learning outcomes is highly influenced by the situation and condition of their 
family environment. It can be said that the level of the students' improvement is influenced by their family environment,

The analysis results that has been analyzed, it was found that family environment affected social sciences learning outcomes which the correlation value $r_{x y}=0,398$ is higher than $r_{\text {table }}$ at the $5 \%$ significance level. It means that there was a significant correlation between family environment and students' social sciences learning outcomes during the COVID-19 pandemic of the fourth-grade students of SD Gugus I, Tabanan District with a large contribution of 15,8\%. From the analysis that had been done, it is found that family environment influenced the students learning outcomes. A harmonious family environment gave positive impacts to the students' improvement, especially their learning improvement. In a family environment, the students get all lot of love, attention, and both moral and material supports that given by their family members. In this COVID-19 pandemic, family environment greatly contributes a huge impact for the students' learning success because the teaching-learning process was carried out online and the teachers are limited to provide guidance to the students. With the attention from their family environment especially from their parents, all of their learning difficulties can be solved well and it influence their learning outcomes.

Based on the research conducted by Krisna states that there was a significant correlation between family environment and social sciences learning outcomes, the $r_{x y}=0,724$ and a large contribution of $52,4 \%$ (Krisna, 2020). Moreover, research conducted by Sulistiari which obtained the $t_{\text {counted }}=3,348$ is higher than $t_{\text {table }}=1,973$ at $5 \%$ significance level. Because of that the family environment had a significant impact on students' learning outcomes (Sulistiari, 2018). Along with it, the research conducted by Monika who showed that family environment had a positive and significant correlation family environment and learning outcomes, the $\mathrm{r}_{\mathrm{xy}}=0,645$ and a large contribution of 41,6\% (Monika, 2018). Based on this study which had been described, the higher attention from the students' family environment, the higher score of their learning outcomes. The students' high learning outcomes are not only influenced by the internal factor but also influenced by the external factor, one of it is family environment. The factors of family environment that influence the learning outcomes such as 1) the way parents educate, 2) the relationship between family members, 3) home atmosphere, 4) family economic condition, 5) parents' attention, and 6) cultural background (M. M. Jamil, 2019; Slameto, 2010).

The way parents educate their children must be right because parents' education is crucial for the children's learning. Parents who educate their children spoiled or with violence which causes the children have lack of enthusiasm and efforts in learning. The harmonious relationship between family members also influence their learning success. Because of it, the students get a lot of passion and care from all family members. It also motivates the students to learn and obtain maximum learning outcomes. A clean and comfortable home really supports students to learn at home especially in this COVID-19 pandemic. It is needed to make them focus and learn comfortably while teaching-learning process. The family economic condition also considers the success of students' learning because they have to fulfill all of the learning needs that support the students to get maximum learning outcomes. Besides, the parents' attention also has a huge impact to their learning success. It supports and motivates them in learning process. Cultural background or habits of students' family also influence their learning success. If their family educate them with the good habits such as disciplines and responsibility, then the students are trained to do all those good habits especially in their learning activities so that they can obtain the maximum learning outcomes. The role of family environment is very crucial for students' learning success. A good family environment has a positive effect to their improvement in learning.

Based on the research finding and discussion above, it can be concluded that there is a significant correlation between family environment and social sciences learning outcomes during the COVID-19 pandemic of the fourth-grade students of SD Gugus I, Tabanan District. The family environment has a good role in improving the students' social sciences learning outcomes. Therefore, parents and other family members must give an extra attention to this case so the children can get their learning success with maximum learning outcomes. Family environment factor can be the success indicator of students learning especially in social sciences subjects and other subjects.

\section{Conclusion}

Based on research problem and research finding that presented previously, it could be concluded that there was a significant correlation between family environment and social sciences learning outcomes during the COVID-19 pandemic of the fourth-grade students of SD Gugus I, Tabanan District. According to the finding of this study which had been described, it is suggested to all students to take the advantages of the family environment to get motivation and support that can improve their learning achievement. In addition, it is also suggested for all parents to improve their attention to the children and 
create a good and comfortable environment in order to increase the children's enthusiasm in learning process. Moreover, as a suggestion for all teachers to be more creative in teaching in case of giving a meaningful and memorable teaching-learning process so the students do not get bored easily during the class.

\section{References}

Agot, K., Rusno, R., \& Walipah, W. (2019). Analisis Faktor Yang Mempengaruhi Prestasi Belajar Mata Pelajaran Di Smp Negeri 03 Kepanjen. Jurnal Riset Pendidikan Ekonomi, 4(1), 1-6. https://doi.org/10.21067/jrpe.v4i1.3771.

Barsihanor. (2016). Pengaruh Model Pembelajaran Cooperative Learning Teknik Inside Outside Circle Terhadap Hasil Belajar Siswa Bidang Studi IPS MI Darul Mujahidin. Jurnal Madrasah Ibtidaiyah, 1(2), 20-30. https://ojs.uniska-bjm.ac.id/index.php/muallimuna/article/view/382.

Brooman, S., \& Darwent, S. (2014). Measuring the beginning: a quantitative study of the transition to higher education. Studies in Higher Education, 39(9), 1523-1541. https://doi.org/10.1080/03075079.2013.801428.

Cho, M. J., \& Hong, J. P. (2021). The emergence of virtual education during the COVID-19 pandemic: The past, present, and future of the plastic surgery education. Journal of Plastic, Reconstructive and Aesthetic Surgery, xхxx. https://doi.org/10.1016/j.bjps.2020.12.099.

Christina, L. V., \& Kristin, F. (2016). Efektivitas Model Pembelajaran Tipe Group Investigation (Gi) Dan Cooperative Integrated Reading and Composition (Circ) Dalam Meningkatkan Kreativitas Berpikir Kritis Dan Hasil Belajar Ips Siswa Kelas 4. Scholaria: Jurnal Pendidikan Dan Kebudayaan, 6(3), 217. https://doi.org/10.24246/j.scholaria.2016.v6.i3.p217-230.

Crawford, J., Butler-henderson, K., Rudolph, J., Malkawi, B., Glowatz, M., Magni, P. A., \& Lam, S. (2020). COVID-19: 20 countries' higher education intra-period digital pedagogy responses. Journal of Applied Learning \& Teaching, 3(1). https://doi.org/10.37074/jalt.2020.3.1.7.

Dahlstrom-Hakki, I., Alstad, Z., \& Banerjee, M. (2020). Comparing synchronous and asynchronous online discussions for students with disabilities: The impact of social presence. Computers and Education, 150(June 2019), 103842. https://doi.org/10.1016/j.compedu.2020.103842.

Ding, J., Hermawati, D., \& Subakti, H. (2020). Analisis Media Pembelajaran Daring Di Era Pandemi Covid-19 Pada Kelas III SD Negeri 027 Samarinda Ulu. Sistema: Jurnal Pendidikan, 01(02), 16-23. https://doi.org/10.24903/sjp.v1i2.639.

Dwivedi, Y. K., Hughes, D. L., Coombs, C., Constantiou, I., Duan, Y., Edwards, J. S., Gupta, B., Lal, B., Misra, S., Prashant, P., Raman, R., Rana, N. P., Sharma, S. K., \& Upadhyay, N. (2020). Impact of COVID-19 pandemic on information management research and practice: Transforming education, work and life. International Journal of Information Management, 55, 102211. https://doi.org/10.1016/j.ijinfomgt.2020.102211.

Fanny, A. M., \& Suardiman, S. P. (2013). Pengembangan Multimedia Interaktif untuk Mata Pelajaran Ilmu Pengetahuan Sosial (IPS) Sekolah Dasar Kelas V. Jurnal Prima Edukasia, 1(1), 1. https://doi.org/10.21831/jpe.v1i1.2311.

Handayani, T., Khasanah, H. N., \& Yoshinta, R. (2020). Pendampingan Belajar Di Rumah Bagi Siswa Sekolah Dasar Terdampak Covid-19. ABDIPRAJA (Jurnal Pengabdian Kepada Masyarakat), 1(1), 107. https://doi.org/10.31002/abdipraja.v1i1.3209.

Jamil, H. (2014). Pengaruh Lingkungan Keluarga dan Motivasi Belajar Siswa Terhadap Hasil Belajar Akuntansi Siswa Kelas X SMK Negeri 1 Solok Selatan. Jurnal of Economic and Economic Education, 2(2). https://doi.org/10.22202/e conomica.2014.v 2.i2.221.

Jamil, M. M. (2019). Optimalisasi Model ARCS Dalam Pembelajaran Saintifik Untuk Meningkatkan Motivasi Belajar Peserta Didik Pada Peminatan Mata Pelajaran Geografi Di Kelas Matematika Ilmu Alam. IJIS Edu: Indonesian Journal of Integrated Science Education, 1(1), 7-24. https://doi.org/10.29300/ijisedu.v1i1.1401.

Krisna, R. (2020). Korelasi Antara Lingkungan Keluarga dan Gaya Belajar Siswa Terhadap Hasil Belajar IPS. Jurnal Mimbar Ilmu, 25(3). https://doi.org/10.23 887/mi.v25i3.28984.

Lenmita. (2020). Meningkatkan Hasil Belajar IPS Siswa Sekolah Dasar Melalui Penerapan Model Pembelajaran Inkuiri. Jurnal Education and Development, 8(4). https://doi.org/10.37081/ed.v8i4.2186.

Monika. (2018). Pengaruh Lingkungan Keluarga dan Lingkungan Sekolah Terhadap Hasil Belajar Bahasa Indonesia Siswa SMP Negeri 11 Merauke Di Sota Papua. Jurnal Magistra, 5(2). http://ejournal.unmus.ac.id/index.php/magistra.

Purandina, I. P. Y., \& Winaya, I. M. A. (2020). Pendidikan Karakter di Lingkungan Keluarga Selama 
Pembelajaran Jarak Jauh pada Masa Pandemi COVID-19. Cetta: Jurnal Ilmu Pendidikan, 3(2), 270290. https://doi.org/10.37329/cetta.v3i2.454.

Putria, H., Maula, L., \& Uswatun, D. (2020). Analisis Proses Pembelajaran Dalam Jaringan (DARING) Masa Pandemi COVID-19 pada Guru Sekolah Dasar. Jurnal Basicedu, 4(4), 861-870. https://doi.org/10.31004/basicedu.v4i3.416.

Rachmah. (2019). Pengaruh Lingkungan Keluarga dan Fasilitas Belajar pada Prestasi Belajar IPS Siswa Ditinjau dari Motivasi Belajar. Jurnal Pendidikan, 4(9). https://doi.org/10.17977/jptpp.v4i9.12701.

Rahayu, S. (2016). Hubungan Lingkungan Keluarga Terhadap Hasil Belajar Sosiologi Di SMA Negeri 16 Padang. Jurnal Ilmu Sosial Mamangan, 5(1). https://doi.org/10.22 202/mamangan.1929.

Rahayu, Sri. (2016). Hubungan Lingkungan Keluarga Terhadap Hasil Belajar Sosiologi Di SMA Negeri 16 Padang. Jurnal Ilmu Sosial Mamangan, Volume 5(1). https://doi.org/http s://doi. org/10.22 202/mamangan.1929.

Rahayu, T., \& Thomas, P. (2017). Pengaruh Kompetensi Profesional Guru Dan Minat Belajar Terhadap Hasil Belajar Siswa Melalui Motivasi Belajar Sebagai Variabel Interrvening Pada Mata Pelajaran Ekonomi. Economic Education Analysis Journal, 6(3), 711-726.

Sadikin, A., \& Hamidah, A. (2020). Pembelajaran Daring di Tengah Wabah Covid-19. Jurnal Ilmiah Pendidikan Biologi, 6(02), 214-224. https://doi.org/10.22437/bio.v6i2.9759.

Satrianingrum, A. P., \& Prasetyo, I. (2020). Persepsi Guru Dampak Pandemi Covid-19 terhadap Pelaksanaan Pembelajaran Daring di PAUD. Jurnal Obsesi : Jurnal Pendidikan Anak Usia Dini, 5(1), 633. https://doi.org/10.31004/obsesi.v5i1.574.

Slameto. (2010). Belajar dan Faktor-Faktor yang Mempengaruhinya. Rineka Cipta.

Sugiyono. (2017). Metode Penelitian Kuantitatif, Kualitatif, dan R \& D. CV Alfabeta.

Sulistiari. (2018). Pengaruh Motivasi, Tipe Belajar, Lingkungan Keluarga, dan Lingkungan Masyarakat Terhadap Hasil Belajar Siswa. Jurnal Pendidikan Ekonomi, Manajemen, Dan Keuangan, 2(1), 57-70. https://doi.org/10.2674 0/jpeka.v 2n1.p57-70.

Wargadinata, W., Maimunah, I., Dewi, E., \& Rofiq, Z. (2020). Student's Responses on Learning in the Early COVID-19 Pandemic. Tadris: Jurnal Keguruan Dan Ilmu Tarbiyah, 5(1), 141-153. https://doi.org/10.24042/tadris.v5i1.6153. 